\title{
Difficulties of E-banking Advancement in Bangladesh
}

\author{
Mohammad Shamsus Sadekin ${ }^{1, *}$, Md. Abdul Hannan Shaikh ${ }^{2}$ \\ ${ }^{1}$ Department of Humanities, Chittagong University of Engineering \& Technology, Chittagong, Bangladesh \\ ${ }^{2}$ Department of Management, Islamic University, Kushtia, Bangladesh
}

\section{Email address:}

sadekinmba@yahoo.com (M. S. Sadekin)

${ }^{*}$ Corresponding author

\section{To cite this article:}

Mohammad Shamsus Sadekin, Md. Abdul Hannan Shaikh. Difficulties of E-banking Advancement in Bangladesh. Science Journal of Business and Management. Vol. 4, No. 3, 2016, pp. 67-71. doi: 10.11648/j.sjbm.20160403.11

Received: April 2, 2016; Accepted: April 13, 2016; Published: May 7, 2016

\begin{abstract}
E-banking implies provision of banking products and services through electronic delivery channels. It permits anytime, anywhere and any how banking. It offers easy, faster, convenient, low cost banking services around the clock. The study was designed to difficulties of e-banking advancement in Bangladesh. No comprehensive study has yet been conducted especially on advancement of e-banking in Bangladesh. The investigation was concentrated in various divisions, districts, towns and rural areas in Bangladesh. The study has been conducted mainly based on primary data. Secondary data has also been used for this purpose. To collect information of e-banking advancement in Bangladesh the websites of related banks were used. Primary data was collected by providing questionnaire to the respondents through e-mail and researcher's direct physical communication. Response from total 120 respondents consisting of 44 bankers and 76 bank customers were selected randomly for the study were considered. In analyzing data, the statistical tools have used with the aid of SPSS software. The result shows that almost all Bangladeshi banks offer e-banking services. State owned commercial banks are in backward position. Quality of e-banking services in Bangladesh is not good. E-banking practice in Bangladesh is not highly secured and Bangladeshi users have lack of awareness about e-banking security.
\end{abstract}

Keywords: E-banking, ATM, POS

\section{Introduction}

"E-banking is an umbrella term for the process by which a customer may perform banking transactions electronically without visiting a brick and mortar institution" [1]. The target of this study is to provide an exemplary analysis of difficulties of e-banking advancement in Bangladesh. Second target is to explain how they have been solved. This will happen on the basis of two perspectives (bank vs. user). Finally, most important learning as well as future trends and further improvements will be summarized. .To access online banking, a customer would go to the financial institution's secured website, and enter the online banking facility using the customer number and password previously setup. Some financial institutions have set up additional security steps for access to online banking, but there is no consistency to the approach adopted [2]. Most of our bank has not any marketing or sales forces to execute the raw and cold business of electronic banking for their own organization.
People are not also conscious about the advantages of the technology [3]. Almost all the banks are providing internet banking to their customers. Most of the banks are having limited number of branches mainly in urban areas. But vast majority of the population residing in rural area are unable to avail the opportunities of internet banking. The price of the internet connection in Bangladesh is higher compared to the neighboring countries [4]. Dealing officials of the banks are not well conversant about their desk work. Monetary gain of both producer and customer may have a feasible and positive impact on raising gross domestic product. E-business, especially with the help of on-line banking, can manage economy of Bangladesh in a better way as customer will be satisfied. E-business is still not very much progressed in Bangladesh. Mass awareness is not feasible [5]. A broad spectrum of electronic banking services, a subject of efinance, is available in Bangladesh with various degree of presentation. Credit card and POS services are provided by $23 \%$ of banks. Several thousand of POS terminals have been 
set in major cities of the countries. Tele banking is second most presented e-banking service in Bangladesh. ATM is expanding in major cities. A group of domestic and foreign banks operate shared ATM network, which drastically increase access to this type of electronic banking service. The network will gradually be extended to other parts of the country. Credit card is also becoming very popular service in major cities in Bangladesh [6]. Electronic banking (ebanking) involves many different types of transactions; it is a form of banking where funds are transferred through an exchange of electronic signals between financial institution, rather than exchange of cash, cheques or other negotiable instruments.

\section{Literature Review}

A number of research studies have been conducted on adoption, practice, impact and securities of e-banking in home and abroad. Some of the relevant studies reviewed and presented below in accordance to year (present to previous) of publication. Islam [7] has conducted a study on "Proposed ICT infrastructure for E-banking in Bangladesh." and found that as a third-world developing country, Bangladesh is far behind to reach the expected level in global banking system. Currently some of the banks of Bangladesh are providing electronic services to their customers. None can say that Bangladeshi banks are completely following e-banking system. Because they offer some of the functionalities of the complete electronic banking. Al-Amin [8] has accompanied a study on "Application of Electronic Banking in Bangladesh: An Overview" and presented that E-banking will be possible only when there will be political commitment with better IT infrastructure, internal network, country domain, and above all a high speed fiber optic link to the information super highway. Hasan et.al. [9] wrote an article on "Adoption of ebanking in Bangladesh: An exploratory study". The study showed that e-banking serves several advantages to Bangladeshi banking sector, however, this study also observed that the Bangladeshi customers have not enough knowledge regarding e-banking which is rendering by banking sector in Bangladesh. Biswas et. al. [5] conducted a study on "Electronic Banking in Bangladesh: Security Issues, Forms, Opportunities and Challenges" and reveal that With the expansion of global Information and Communication Technology (ICT) infrastructure and the internet, e-banking is set to play a pivotal role in the national economic development of any country. But appropriate software, technology, infrastructure, skilled manpower and cyber law are crucial for the implementation of e-banking in the country. Some other studies were conducted on "E-Banking of Economical Prospects in Bangladesh" Baten and Kamil
[6], "Problems and prospects of e-banking in Bangladesh." Khan \& Kamaruzzaman [10], "Online Banking in Bangladesh An Empirical Analysis.” Rahman H et.al. [11] have done a study on "Problems and prospects of e-banking in Bangladesh." but that was true for 2012, Mondal and Saha [12] "Client Satisfaction of Internet Banking Services in Bangladesh: An Exploratory Study." The current status of ebanking in Bangladesh is different from previous time. Many limitations of e-banking were solved by this time. So a comprehensive study was needed to find out the difficulties of e-banking advancement in Bangladesh. If the findings of this study will be solved by the authority e-banking in Bangladesh will run in same speed as developed country.

\section{Methodology of the Study}

The study has been conducted mainly based on primary data. Secondary data has also been used. Secondary data has been collected from different books, journals, seminar paper, research reports, official reports, periodicals, survey reports, web-sites, annual reports and others. Primary data has been collected from 16 banks. Branches are located in Dhaka, Chittagong, Rajshahi, Rangpur and Khulna Division and 120 Samples were selected purposively from both bankers and bank customers, and the responses from both the groups are analyzed and presented. To collect data two set of questionnaire including 24 questions were provided to bankers and bank customers to collect information separately. There has 07 common questions about the profile of respondents and rests of the questions are different for customers and bankers. Customer's questions were related their difficulties of making transaction in e-banking system and its security gap which are the barrier of e-banking advancement in Bangladesh. The banker's questions were mainly related with the problem maintaining e-banking procedures and security protection of related bank. In some questions the respondents were fill up the gap by mentioning the difficulties of e-banking advancement in Bangladesh and some other questions the participants were asked to indicate their perception on a liker the scales (1-5) with response ranging from "Very bad" to "Excellent". Some questions were added in the questionnaire where had sufficient space to mention the difficulties of e-banking advancement in Bangladesh.

\subsection{Analysis of Data}

Response from total 120 respondents consisting of 44 bankers and 76 bank customers, 98 male and 22 female, 34 married and 86 unmarried, and 28 from rural and 92 from urban areas selected randomly for the study were considered.

Table 1. E-Service Quality of Bangladeshi Banks.

\begin{tabular}{lllll}
\hline \multirow{2}{*}{$\begin{array}{l}\text { E-Service } \\
\text { Quality of }\end{array}$} & \multicolumn{2}{l}{ Bank's Classification } & & \\
\cline { 2 - 5 } Bangladeshi & State Owned Commercial Banks (\%) & Domestic Private Commercial Banks & Foreign Commercial Banks \\
nyynks & Not Good & 47 & 06 & 08 \\
Banks & $(39.17)$ & $(5)$ & $(6.67)$ \\
& Satisfactory & 44 & 49 & 25 \\
\hline
\end{tabular}




\begin{tabular}{llll}
\hline & $(36.67)$ & $(40.83)$ & $(20.83)$ \\
Very Good & 19 & 41 & 46 \\
& $(15.83)$ & $(34.17)$ & $(38.33)$ \\
Excellent & 10 & 24 & 41 \\
Total & $(8.33)$ & $(20)$ & $(34.17)$ \\
\hline
\end{tabular}

It is gained from Table 1 that among the respondents $47 \%$ give their opinion that e-service quality of state owned commercial banks in Bangladesh is "not good" only $8.33 \%$ feel that the quality is "excellent", $40 \%$ respondents said eservice quality of domestic private commercial banks is "satisfactory" and 5\% mentioned their service quality is "not good" $41 \%$ respondents mentioned that the e-service quality of foreign commercial banks is "excellent" and 6.67\% said this is "not good".

Table 2. The Availability of Professional Degree of E-Banking Users.

\begin{tabular}{llll}
\hline Professional Degree & Frequency & Percent & Cumulative Percent \\
\hline Yes & 27 & 22.5 & 22.5 \\
No & 93 & 77.5 & 100 \\
\hline
\end{tabular}

Only $22.5 \%$ respondents have professional degree on computer or internet. This is a barrier for electronic banking in Bangladesh. Majority of the bankers and customers haven't sufficient knowledge on IT based devices and some of them are also afraid of using computer.

Table 3. Availability of Personal Computer in the Residence.

\begin{tabular}{llll}
\hline Personal Computer & Frequency & Percent & Cumulative percent \\
\hline Yes & 88 & $73 \%$ & 73 \\
No & 32 & $27 \%$ & 100 \\
\hline
\end{tabular}

Majority of the respondents $(73.33 \%)$ have personal computer but $26.67 \%$ respondents have no computer in their residence which is one of the main difficulties of e-banking promotion in Bangladesh. This type of user depends on cyber cafe or other's computer which is a problem of e-banking security.

Table 4. Name of Internet Connection and Browser Used by the Respondents.

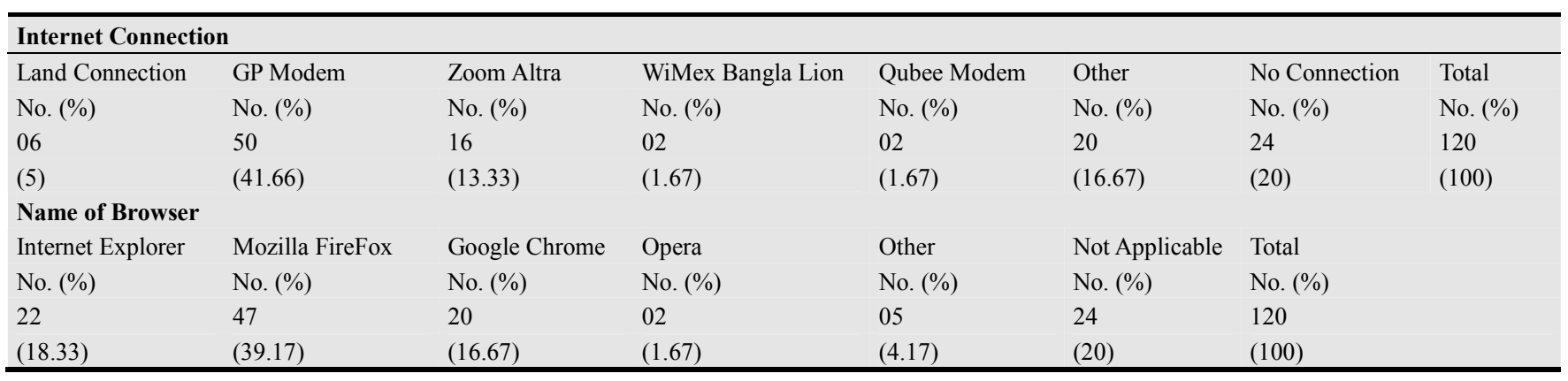

Table 4 shows that $41.67 \%$ respondents use GP modem for internet connection, $20 \%$ respondents has no connection, $13.33 \%$ respondents use Zoom Altra for internet connection and $39.17 \%$ respondents use Mozilla Fire Fox as their internet browser, $18.33 \%$ use Internet Explorer, 16.67\% respondents use Google Chrome and $4.17 \%$ respondents use other operating browser and 20\% respondents do not use internet. Majority Bangladeshi (74.17\%) users use Fire Fox, Internet Explorer or Google Chrome.

Table 5. Security Problem from Hijacker.

\begin{tabular}{llll}
\hline Security Problem & Frequency & Percent & Cumulative Percent \\
\hline Yes & 59 & 49.1 & 49.1 \\
No & 61 & 50.9 & 100 \\
Total & 120 & 100 & \\
\hline
\end{tabular}

It is obtained from Table 5 that e-banking in Bangladesh is not free from security problem of hijacker. Customers feel insecurity to withdraw money from ATM booths. In this research 49.1 percent respondents feel security problem from hijacker to withdraw and deposit money in ATM booths.
Table 6. ATM Booths Location and Security of E-Banking.

\begin{tabular}{llll}
\hline Secured Location & Frequency & Percentage & Cumulative Percentage \\
\hline Yes & 42 & $35 \%$ & 35 \\
No & 78 & $65 \%$ & 100 \\
\hline
\end{tabular}

Table 6 shows that among the respondents $65 \%$ respondents mentioned ATM booths of Bangladeshi banks are not in secured location.

Table 7. Security Level of E-Banking in Bangladesh.

\begin{tabular}{llll}
\hline Security of E-Banking & Frequency & Percent & Cumulative Percent \\
\hline Highly Secured & 18 & 15.0 & 15.0 \\
Sufficient Secured & 50 & 41.7 & 56.7 \\
Not Enough Secured & 38 & 31.7 & 88.3 \\
Not Secured at all & 1 & .8 & 89.2 \\
Don't Know & 13 & 10.8 & 100.0 \\
Total & 120 & 100.0 & \\
\hline
\end{tabular}

Among the respondents $15 \%$ said e-banking is highly secured, $41.7 \%$ said sufficient secured, $31.7 \%$ said not enough secured $10.8 \%$ don't know about the security level of e-banking. 
Table 8. Antivirus Used by the Respondents.

\begin{tabular}{lllllllll}
\hline Kasp-ersky & AVG & Avast & Norton & Avira & Smut Security & E-net NOD & No Anti-virus & Total \\
\hline No. (\%) & No. (\%) & No. (\%) & No. (\%) & No. (\%) & No. (\%) & No. (\%) & No. (\%) & No. (\%) \\
\hline 39 & 05 & 33 & 06 & 02 & 02 & 01 & 32 & 120 \\
$(32.5)$ & $(4.2)$ & $(27.5)$ & $(5)$ & $(1.7)$ & $(1.7)$ & $(.8)$ & $(27)$ & $(100)$ \\
\hline
\end{tabular}

Among the respondents $32.5 \%$ uses Kesparsky, 27.5\% uses Avast, 27\% don't use any anti-virus.

Table 9. Major Barriers of E-Banking Advancement in Bangladesh Mentioned by the Respondents.

\begin{tabular}{lllllll}
\hline $\begin{array}{l}\text { Software } \\
\text { Security Gap }\end{array}$ & Power Crisis & $\begin{array}{l}\text { Lack of Technical } \\
\text { Knowledge }\end{array}$ & $\begin{array}{l}\text { Customer's Dependency } \\
\text { on Bankers }\end{array}$ & $\begin{array}{l}\text { Gap of Trust on } \\
\text { e-banking }\end{array}$ & $\begin{array}{l}\text { Infrastructural } \\
\text { Gap }\end{array}$ & $\begin{array}{l}\text { Lack of } \\
\text { Monitoring }\end{array}$ \\
\hline No $\mathbf{( \% )}$ & No. $(\%)$ & No. $(\%)$ & No. $(\%)$ & No. $(\%)$ & No. $(\%)$ & No. $(\%)$ \\
\hline 85 & 85 & 44 & 39 & 56 & 72 & 61 \\
$(70.83)$ & $(71)$ & $(36.67)$ & $(32.5)$ & $(46.67)$ & $(60)$ & $(50.83)$ \\
\hline
\end{tabular}

Among the respondents $70.83 \%$ mention that the software used by the banks in Bangladeshi banks are not sufficient secured, $71 \%$ said there has electricity crisis, $36.67 \%$ feel that Bangladeshi users don't have sufficient technical knowledge, 32.5\% remark that Bangladeshi customers are dependent on bankers to create account in e-banking system and bankers provide password for these customers, $46.67 \%$ account holders do not have trust on the security of e-banking system in Bangladesh, $60 \%$ respondent's observation is that Bangladesh didn't have sufficient required infrastructure of e-banking and finally $50.83 \%$ respondents mentioned that the authority doesn't monitor the e-banking system properly.

\subsection{Findings}

i. E-Banking Service Quality: Bangladeshi banks do not provide best quality of e-banking services to their customers. It is gained from Table 1 that among the respondents $8.33 \%$ state owned commercial banks, $20 \%$ domestic private commercial banks and $34.17 \%$ foreign commercial banks provide excellent quality e-service in Bangladesh. [see Table 1]

ii. Lack of Technical Knowledge of Bankers: Banks operating in Bangladesh do not have sufficient officers who have technical knowledge to use computer or internet. They have no professional degree or training on computer or internet. Many times they face operating problem and take help from others who are not a banker. This create e-banking security risk. [see Table 9]

iii. Power Crisis: E-banking service is totally dependent on electricity. Till now total power production of Bangladesh is not enough to fulfill the total demand of the country. For this reason load shedding takes place almost in all the area on every day. Though every private commercial bank both foreign and domestic, has own generator to produce power for emergency period. But till now the state owned banks did not provide generator to each and every branches for emergency period. Among the respondents $71 \%$ mentioned that load shedding is one of the main a barrier for proper utilization and expansion of ebanking practices in Bangladesh. [see Table 9] iv. Insufficient Infrastructure: Till now the required infrastructural facilities for e-banking are not available in Bangladesh. Almost all of the banks are dependent to IT firms for essential security software for e-banking. Banks depend on telecommunication companies for internet connections. [see Table 9]

v. Lack of Personal Computer of Customer: It is acquired from the Table 3 that among the respondents $27 \%$ have no personal computer in their residence. Without personal computer e-banking function cannot be performed properly.

vi. Internet Connection: It is attained from the Table 4 that among the respondents $18.33 \%$ have no internet connection. Without internet connection e-banking activities cannot be operated rightly.

vii. Slow Internet Speed: Almost all the banks are dependent on telecommunication companies for their internet connection. These companies are unable to provide high speed internet services to its clients. It is found from the Table 4 that among the respondents $30 \%$ mentioned the speed quality of internet connections is slow.

viii. Insecurity from Hijacker: Customers feel insecurity from hijacker to withdraw and deposit money. Table 5 indicates that among the respondents $49 \%$ perceived insecurity from hijacker.

ix. Location of ATM Booths: All the ATM booths of Bangladeshi banks are not in safe position. It is investigated from the Table 6 that among the respondents $65 \%$ said that the locations of ATM booths in Bangladesh are not in safe and secured location.

x. Lack of Locally Produced Software: Banks operating in Bangladesh are using foreign software. Local Banking software should be developed for the smooth and safe practices of e-banking.

xi. Poor Economic Condition of Customers: Bangladeshi customers who take e-banking services a big percentage of them are not capable of bearing the cost of additional equipment like computer, computer accessories, internet connectivity etc. Using Internet facility still very costly and people has little 
knowledge in operating computers. A few number of cyber café is available but for e-banking purpose customers do not feel safe to use these facilities.

xii. Lack of Awareness: E-banking is still not very much advanced in Bangladesh. This is due to lack of mass awareness.

xiii. Security Status: It is grasped from the Table 7 that, EBanking is not highly secured in Bangladesh. Among the respondents $41.7 \%$ said that e-banking security in Bangladesh is sufficient but $31.7 \%$ said, e-banking in Bangladesh is not enough secured. Only $15 \%$ said ebanking in Bangladesh is "highly secured". There have some e-banking security problems in Bangladesh; as a result some unwanted occurrences have been taken place.

xiv. Antivirus: It is obtained from Table 8 that there is a significant positive correlation between antivirus in PC and hacking of e-account. Customers who do not use antivirus their account are less secured.

xv. Trust on E-banking System: It is gained from Table 9 that $46.67 \%$ respondents do not trust on the security of e-banking system.

\section{Conclusion}

E-Banking is a new concept in banking sector of Bangladesh. It is becoming popular in Bangladesh; thus almost all Bangladeshi banks offer many facilities of ebanking. E-banking is growing in Bangladesh day by day. All types of e-banking services are being appreciated and applied by people of different walks as this eases the activities. So, such an attractive offer package provided by e-banking will be popular everywhere very soon. But the security concern should maintain straightly to increase the trust of customer in e-banking services. Initiatives are to be taken to make it more secure. As Bangladeshi bank customers have limited knowledge on transactions and e-services. So they are not ready to accept any financial difficulties and further they will not trust on e-banking services. So bankers have to be sincere about e-banking security. . If necessary initiative can be taken in the light of findings of the study like improvement of quality of e-banking service, removing insecurities, infrastructural development, continuous power supply, close circuit camera, increasing internet speed, increase awareness, using protection password and antivirus, formulation of ebanking supporting policies, reducing tax on e-banking equipment, close monitoring, legal provisions for controlling frauds and malpractices etc.

\section{References}

[1] Gerrard P, Cunningham J. B. (2003) "The Diffusion of Internet Banking Among Singapore Consumers.” International Journal of Bank Marketing, 21(1), 16-28.

[2] Cronin, Mary J (1997) "Banking and Finance on the Internet." John Wiley and Sons. ISBN 0-471-29219-2 page 41 From Banking and Finance on the Internet. Retrieved 2008-07-10.

[3] Bony S Z and Kabir F (2013) "Practice of E-banking in commercial bank: An empirical study in Bangladesh" International Journal of Business and Social Research (IJBSR), Volume -3.

[4] Islam M M (2015) "Challenges and Prospects of Internet Banking in Bangladesh: Banker's (Service Providers) Point of View".

[5] Biswas, Shyamapada et.al. (2011). "Electronic Banking in Bangladesh: Security Issues, Forms, Opportunities and Challenges." Canadian Journal on Scientific and Industrial Research. Vol. 2.

[6] Baten, M A and Kamil A A (2010) "E-Banking of Economical Prospects in Bangladesh.” Journal of Internet Banking and Commerce. Vol. 15.

[7] Islam M M (2005) "Proposed ICT Infrastructure for Ebanking in Bangladesh". Department of Computer and Systems Sciences, Royal Institute of Technology (KTH), Stockholm, Sweden.

[8] Al-Amin S and Rahman S (2010) "Application of Electronic Banking in Bangladesh; An Overview" Bangladesh Research Publication Journal, Volium-4.

[9] Hasan A H M S, Baten M A, Kamil A A and Parvin S (2010) "Adoption of E-Banking in Bangladesh: An exploratory Study.” African Journal of Business Management. Vol.4.

[10] Khan W and Kamruzzaman M (2012) "Problems and Prospects of E-banking in Bangladesh." Development Compilation, Vol. 07. No. 02.

[11] Rahman H et.al. (2012) "Problems and Prospects of EBanking in Bangladesh.” International Journal of Scientific and Research Publications, Volume 2.

[12] Mondal, K. C. and Saha, A. K. (2013). "Client Satisfaction of Internet Banking Service in Bangladesh: An Exploratory Study”, ASA University Review, Vol. 7 No. 1. 